\title{
3
}

\section{Ideal Utilitarianism: Rashdall and Moore}

\author{
Anthony Skelton ${ }^{*}$
}

Ideal utilitarianism states that the only fundamental requirement of morality is to promote a plurality of intrinsic goods for all those capable of possessing them. This moral framework flourished in the middle part of the period between Henry Sidgwick and A. C. Ewing. It was defended by John Laird, H.W. B. Joseph, G. E. Moore, and Hastings Rashdall, among others. According to Ewing: 'The best expositions of this type of view in English are Moore's Principia Ethica and Ethics and Rashdall's Theory of Good and Evil." Moore's arguments for ideal utilitarianism are well known, and therefore serve as the focus of most discussions of it. ${ }^{2}$ Rashdall's are not, despite the fact that his The Theory of Good and Evil was referred to in his time as 'certainly at least one of the most important works on ethical theory of our generation'. ${ }^{3}$ The discussions that do focus on both Moore and Rashdall ignore or obscure the fact that they do not employ the same gamut of arguments for the position. ${ }^{4}$ In a series of articles and books which began appearing near the end of the nineteenth century Rashdall produced distinct arguments for the view. ${ }^{5}$ To properly understand the development of ideal utilitarianism it is therefore necessary to consider Rashdall's contribution to it.

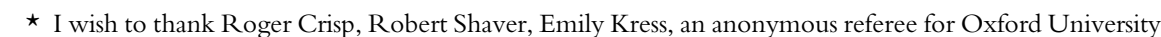
Press and, especially, Thomas Hurka for extremely valuable written comments on previous drafts.

1 A. C. Ewing, 'Recent Developments in British Ethical Thought', in C. A. Mace (ed.), British Philosophy in the Mid-Century: A Cambridge Symposium (London: George Allen \& Unwin, 1957), 69.

${ }^{2}$ See e.g. Mary Warnock, Ethics Since 1900 (Oxford: Oxford University Press, 1960); Tim Mulgan, Understanding Utilitarianism (Stocksfield: Acumen, 2007); William H. Shaw, Contemporary Ethics: Taking Account of Utilitarianism (Oxford: Blackwell, 1999); Julia Driver, 'The History of Utilitarianism', in Edward N. Zalta (ed.), The Stanford Encyclopedia of Philosophy (Summer 2009) http://plato.stanford.edu/archives/ sum2009/entries/utilitarianism-history/; and Ewing, 'Recent Developments'.

3 William K. Wright, 'Review of Hastings Rashdall, Is Conscience an Emotion?', Philosophical Review, 25 (1916), 81.

${ }^{4}$ See e.g. Geoffrey Scarre, Utilitarianism (London: Routledge, 1996).

5 Works by Rashdall are abbreviated as follows. TGE 1 and TGE 2: The Theory of Good and Evil, vols. 1 and 2 (London: Oxford University Press, 1907); PU: 'Professor Sidgwick's Utilitarianism', Mind, 10 (1885); E: Ethics (London: T. C. \& E. C. Jack, 1913); CE: Is Conscience an Emotion? (Boston: Houghton Mifflin, 1914). 


\section{ANTHONY SKELTON}

The principal aim of this chapter is to provide a reconstruction and critical evaluation of Rashdall's main arguments for ideal utilitarianism, with special emphasis on how they compare with Moore's arguments. In section I, I briefly outline the basic features of his ethical outlook. In section II, I consider two different positive arguments that Rashdall provides for its theory of rightness, one of which relies on definitions of moral terms and one of which relies on an appeal to abstract self-evident propositions. I raise worries about both argumentative strategies. In section III, I discuss his arguments in favour of a pluralist theory of value. I argue that Rashdall's most promising argument relies on an appeal to common-sense morality. In section IV, I conclude by sketching how Rashdall makes a more lasting contribution to the defence of ideal utilitarianism than does Moore.

\section{I}

Rashdall's ideal utilitarianism contains both a theory of rightness and a theory of value. He holds that the morality of an action, rule, policy, or institution is determined solely by the value or goodness of the state of affairs that it results in (TGE 1.100, 184, 219; $E$ 60, 71). For Rashdall, the 'right action is always that which (so far as the agent has the means of knowing) will produce the greatest amount of good upon the whole' (TGE 1.184). ${ }^{6}$ The value of a state of affairs is determined not only by the sum total of pleasure that the state of affairs includes, but by the sum total of the goods of virtue, knowledge, and pleasure (TGE 1.76; E 69-70; CE 44). ${ }^{7}$ These values are 'intuitively discerned and compared with one another by the moral or practical Reason' (TGE 1.184; also 100). They function to assess the value of a life as a whole rather than how things are going at a particular moment or time in a life (TGE 1.220; TGE 2.40; E 71). Rashdall does not think that the goods which make up the conception of the ultimate end are of the same axiological significance. He holds that virtue is more important than intellectual activity which is more important than mere pleasant feeling (TGE 1.76, 191; CE 44). He further contends that a sufficient amount of a lower good can outweigh a lesser amount of a higher good (TGE $2.42 \mathrm{ff} . ;$ E 68). ${ }^{8}$

\section{II}

G. E. Moore defends a similar view. His arguments for the theory of rightness associated with ideal utilitarianism are not terribly robust. In Principia Ethica he argues

\footnotetext{
${ }^{6}$ Rashdall, perhaps misleadingly, often states that the right action is that which has a tendency to produce the greatest amount of good on the whole (e.g. TGE 1.184; E 77).

${ }^{7}$ He sometimes appears to add a fourth good, 'various kinds of affection or social emotion' (E 70; also TGE 2.37).

${ }^{8}$ Scarre overlooks the fact that Rashdall thinks that virtue may be outweighed by a sufficient amount of a lower good. His ignorance of this fact allows him to claim that Rashdall is actually a virtue theorist. By noting this aspect of Rashdall's view one may block Scarre's suggestion. See Scarre, Utilitarianism, 120-1.
} 
that 'right' means 'what will not cause less good than any possible alternative' and that 'duty' means that 'which will cause more good to exist in the Universe than any possible alternative'. 'Therefore, a position about what is right or what one has a duty to do falls out of a proper analysis of the concept of 'right' or 'duty'. Rashdall seems at times to incline toward this metaethical position. He argues that 'good' is 'logically the primary conception', and that 'right' just means that 'which tends to bring about the good' (TGE 1.135; also E 14, 61). Indeed, he submits that 'the idea of "right" is meaningless apart from a "good" which right actions tend to promote' (TGE 1.138; also TGE 2.42). This explains why (a) he often remarks that 'in ultimate analysis all moral judgements may be reduced to ... judgements of value' ( $E 77$, italics in original; also TGE 1.93, 137, 148, 184; CE 45), and why (b) he seems to think that the claims 'the greater good ought always to be preferred to the less' and 'it is always right to promote the greatest possible good' are equivalent (CE 41; E 40).

In a review of Principia Ethica, Bertrand Russell argues contra Moore that 'it might be proved, in the course of moral exhortation, that such and such an action would have the best results; and yet the person exhorted might inquire why he should perform the action'. ${ }^{10}$ In other words, Russell rightly notes, Moore's own definition of rightness seems to be susceptible to the open-question argument. This convinced Moore. ${ }^{11}$ Russell's criticism is equally effective against Rashdall. In his critical attack on hedonism, Rashdall notes that 'good' does not mean 'pleasure', since 'pleasure is good' is not identical to 'pleasure is pleasant', and therefore not a tautology (TGE 1.48; also E 16, 22). Following Russell, one may argue against Rashdall that 'right' does not mean 'that which produces the greatest good possible', since 'the right action is that which produces the greatest good possible' is not identical to 'the action which produces the greatest good possible produces the greatest good possible', and therefore not a tautology. It is instead a significant proposition: one can be told that an act produces the greatest net good in the circumstances and yet still doubt that it is right or obligatory. A second worry arises for Rashdall: his definitional claims are in tension with his treatment of non-utilitarian moral frameworks. He treats them as intelligible options. The difficulty is that if 'right' has no meaning other than 'means to the greatest attainable good', then the non-utilitarian positions that Rashdall discusses are strictly speaking unintelligible. ${ }^{12}$

In Ethics, Moore provides a different argument for ideal utilitarianism. He contends that 'it seems to me to be self-evident that knowingly to do an action which would

${ }^{9}$ G. E. Moore, Principia Ethica (Cambridge: Cambridge University Press, 1903), 148; italics in original; also 181 (henceforth abbreviated as $P E$ ).

${ }^{10}$ Bertrand Russell, 'The Meaning of Good', in Russell on Ethics, ed. Charles R. Pigden (London: Routledge, 1999), 101.

11 G. E. Moore, 'A Reply to My Critics', in The Philosophy of G. E. Moore, ed. P. A. Schilpp (Chicago: Northwestern University Press, 1942), 558. See also G. E. Moore, Ethics (Oxford: Oxford University Press, 1912 (1961 reprint)), 107-8, for a denial of the claim that 'right' means 'that which causes maximal goodness'.

12 Moore does not have this problem. He does not discuss rival moral views in the way Rashdall does (at least in Principia). 
make the world, on the whole, really and truly worse than if we had acted differently, must always be wrong. ${ }^{13}$ He wields this against non-utilitarian moral views and egoism. ${ }^{14}$ Rashdall seems at times to express sympathy with an argument that involves appeal to self-evident propositions. He accepts the following such propositions, that (1) 'I ought to promote my own good on the whole (where no one else's good is affected)', (2) 'I ought to regard a larger good for society in general as of more intrinsic value than a smaller good', and (3) 'I ought to regard the good of one man as of equal intrinsic value with the like good of any one else' (TGE 1.90-1, 147, 184-5; also 242, $222,263)$. He relies mainly on benevolence, (2), and equity or justice, (3) (E 77; CE 41-2). ${ }^{15} \mathrm{He}$ argues that these propositions oblige us to promote the universal good (TGE 1.91; CE 42-3), that they "direct us as to the way we are to distribute "the good" when we know what it is' (TGE 1.148; also 224, 112), and that though these selfevident propositions do not tell us which 'particular actions are right or wrong', they do tell us what is right or wrong in general (CE 42; TGE 1.112). He claims to borrow these from Henry Sidgwick, and with him Rashdall argues that these are the 'principles upon which a rational Utilitarianism is founded' (E 77; also TGE 1.91, 147). ${ }^{16}$

Moore's appeal to self-evidence is starker than Rashdall's. ${ }^{17}$ The former simply asserts that ideal utilitarianism's theory of rightness is self-evidently true, and that the falsity of rival views follows as a result. Moore does not attempt to examine candidate self-evident propositions in order to determine which are acceptable, and only then conclude that the only acceptable intuitions support utilitarianism. This is Rashdall's strategy. He offers us his self-evident propositions in the context of an argument (following Sidgwick) aimed at showing that utilitarianism is based on a set of selfevident propositions, the truth of which emerges from an assessment of rival views of what is self-evidently true (TGE 1.83-91; E 51-60). The argument seems to be that the only truly plausible self-evident propositions are the ones Rashdall lists, and these support utilitarianism.

But this raises a question. How does Rashdall get from the propositions that he thinks are self-evident to the account of rightness in ideal utilitarianism? He suggests at one point that rational or right conduct consists in 'acting with a clear conception of

13 Moore, Ethics, 112, italics in original; also 143.

14 Ibid. 109-13, 141-3.

15 Rashdall drops the intuition of prudence (1) in later writings (CE 42, $183 \mathrm{n}$. 1). He sometimes suggests, following Sidgwick, that prudence amounts to the requirement of temporal neutrality (PU 202). In this case, it has some role in his argument appealing to self-evident propositions. That he is committed to some kind of temporal neutrality seems implied by his claims about the rights of future generations (TGE 1.228).

16 For an account of the self-evident intuitions on which Sidgwick relies, see Henry Sidgwick, The Methods of Ethics, $7^{\text {th }}$ edn. (London: Macmillan, 1907), 379-82, 400-1 (henceforth abbreviated as ME). For a discussion of Sidgwick's intuitions and the role they play in his argument for utilitarianism, see Anthony Skelton, 'Sidgwick's Philosophical Intuitions', Etica and Politica/Ethics and Politics, 10 (2008).

17 Rashdall does claim at one point that it is self-evident that 'it is always right to promote the greatest possible good' (CE 41; also TGE 1.110). This is bolder than his usual claims, though less bold than Moore's claim, because this statement is consistent with the claim that it is not wrong not to promote the greatest possible good. 
our ultimate purpose or aim, and taking the means which seem best adapted to attain that end' (TGE 1.83-4). His view seems to be that the self-evident propositions of benevolence and equity support the idea that the end that it is right to aim at is maximum social or aggregate good, since a larger amount of the good is always preferable to a smaller amount and since one person's good is to be treated as of the same intrinsic importance as the like good of another person in distributing the good. The burden for the argument lies in showing that these are the only claims regarding how to appropriately distribute the good and in demonstrating that right conduct consists in 'acting with a clear conception of our ultimate purpose or aim, and taking the means which seem best adapted to attain that end' (TGE 1.83-4). Whether this argument succeeds is something we can conclude only after examining Rashdall's main argument against intuitionism, the view that 'actions are pronounced right or wrong a priori without reference to their consequences' (TGE 1.80; also E 45). ${ }^{18}$ If this negative argument is successful, he is free (it seems) to move from the more modest claims in the self-evident propositions to the stronger claims that one finds in his statements of ideal utilitarianism.

This leads us to Rashdall's main argument against intuitionism (TGE 1.83-91; E 51-60). The argument begins by noting some of the defects of the intuitionist's main moral rules: they are often vague, in some cases they conflict with each other, and they admit of exceptions. This is true of, for instance, the rules of justice and promisekeeping. Typically, Rashdall contends, we appeal to consequences to make the rules more precise, to adjudicate conflicts between them and to justify exceptions to them. However, if the more precise rules, the solutions to the conflicts, and the exceptions are justified on the basis of the consequences of acting on them, it follows that in every case in which we act we must determine the outcome of the action in order to determine whether or not the rule or its specification applies, and therefore to determine the morality of the action. It cannot, he continues, logically 'ever be right to exclude consideration of consequences' (TGE 1.87; italics in original; also $E$ 59), from which it follows that only consequences matter to morality $(E 60)$. To this he adds another argument, that in order to determine the morality of, for instance, the act of drunkenness, we must look at its consequences, for 'some consequences are included in the meaning of the act' (E 58, italics in original). ${ }^{19}$ But, 'once admit that consequences must be considered at all, and it is arbitrary to stop at any particular point in the calculus of social effects' (TGE 1.88; also E 58, 59). His basic point appears to be that we do not know what we are required to do until we have figured out the full consequences of our actions, from which it follows that 'it is irrational to judge of the morality of an action without tracing its bearing upon human Well-being as a whole' (TGE 1.91),

\footnotetext{
${ }^{18}$ Rashdall also provides (effective) arguments against Kant (TGE 1.108 ff.). I do not discuss these. Doing so would lead me too far afield.

19 Drunkenness makes a man, for example, 'thick in his speech, unsteady in his gait, erratic in his conduct, incoherent in his thoughts, and so on' (E 58).
} 


\section{ANTHONY SKELTON}

from which it follows that only consequences matter to morality, from which it follows that 'Intuitionism must be regarded as an impossible and obsolete mode of ethical thought' (E 60).

This is not a very good argument. It certainly appears to have had no impact on Rashdall's anti-utilitarian rivals H. A. Prichard, W. D. Ross, and E. F. Carritt. ${ }^{20}$ Ross, for instance, seems to accept that before we can determine that it is right to express gratitude or to keep a promise we need to figure out the consequences of acting on the requirements to keep promises and to express gratitude. ${ }^{21}$ However, he contends that it does not follow from the fact that we need to appeal to consequences to figure out what to do that only consequences matter. The argument that Rashdall provides appears to be a non sequitur. This is presumably in part why it failed to convince rivals.

There is a deeper worry about Rashdall's argument. Elsewhere he argues that all valuable states of consciousness are pleasurable - in part because all desire satisfaction is pleasurable (E 18; TGE 2.53; PU 212) - and that if a state of consciousness fails to be pleasurable, then it is no longer valuable regardless of the other elements that it contains. "Value is not a feeling, but it cannot be recognised as attributable to anything in consciousness which can excite no feeling of pleasure in its possessor' (TGE 1.153-4; also 66, 67, 118 n. 2, 219-20; TGE 2.37, 38; E 69). More tellingly, he writes that 'the value of some things is not measured by their pleasantness, but the value of other things surely does cease to exist when they cease to be pleasant. We must, therefore, be able to estimate their pleasantness before we can pronounce upon their value, and compare that value with the value of things which do not owe their value entirely to their pleasantness' (TGE 2.51). Rashdall does not infer from the fact that we need to determine that a state of consciousness is pleasurable to assess its value that the only thing that ultimately matters is pleasure. That is, he does not conclude from the fact that a valuable state of consciousness must be pleasurable that only pleasure matters. $\mathrm{He}$ wants to resist this implication. He thinks things in addition to pleasure determine the value of a state of consciousness. Pleasure is merely a necessary condition for a state of affairs to be intrinsically valuable.

But note that this is a conclusion quite different from the one that Rashdall comes to in his argument against intuitionism. He argues that because we have to determine all of the consequences of an action before we determine its nature and its morality only consequences matter to morality. He does not, however, conclude that only pleasure matters from the fact that we have to determine that a state of affairs is pleasurable to determine its axiological status. What accounts for the different strategies and

\footnotetext{
${ }^{20}$ H. A. Prichard, 'Does Moral Philosophy Rest on a Mistake?', Mind, 21 (1912), and 'What Is the Basis of Moral Obligation?', in Prichard, Moral Writings, ed. Jim MacAdam (Oxford: Clarendon Press, 2002) (henceforth abbreviated as RM and MO respectively); W. D. Ross, The Right and the Good (Oxford: Oxford University Press, 1930), 17-37 (henceforth abbreviated as RG); E. F. Carritt, The Theory of Morals (Oxford: Oxford University Press, 1928).

21 Ross, RG 41-2. For the same point, see W. D. Ross, Foundations of Ethics (Oxford: Oxford University Press, 1939), 90, 99.
} 
conclusions in the two cases? The general argument against intuitionism seems to be a non sequitur. For intuitionism's defenders can concede Rashdall's claim about the need to determine all of the consequences of one's actions, but argue that (like Rashdall in the instance discussed above) it is still the case that things other than consequences matter to the morality of an action. ${ }^{22}$ Rashdall seems to agree that it would be a non sequitur to argue that because we have to determine the pleasantness of a state of consciousness before determining its value therefore only pleasure is intrinsically valuable. He would reject a hedonist argument according to which his claim about pleasure entails that hedonism is true. But he gives us no reason for accepting his argument against intuitionism and for rejecting a hedonist argument of the same variety.

Rashdall does, of course, claim that an analysis of our moral consciousness reveals that more than pleasure matters (E 28; TGE 2.37, 53; CE 43-4). This will not help. For Ross, Prichard, and Carritt may do the same in support of their view that there is a plurality of moral requirements. In fact, Sidgwick, Carritt, Ross, and Prichard all agree that common-sense morality contains deontological elements. Sidgwick states that the key element of common-sense morality is that 'we have the power of seeing clearly that certain kinds of actions are right and reasonable in themselves, apart from their consequences; - or rather with a merely partial consideration of consequences, from which other consequences admitted to be possibly good or bad are definitely excluded'. ${ }^{23}$ Ross claims of the moral philosopher that 'the verdicts of the moral consciousness of the best people are the foundation on which he must build', and that this leads him to the view that the fact that an 'act will produce the best possible consequences is not... [the] reason for calling it right'. ${ }^{24}$ Prichard declares that it is improper to imply that 'there is a common reason why all right acts are right', and that it is a mistake to attempt to show by means of a theory like ideal utilitarianism that we ought, for example, to keep our promises, since attempting to prove that we have certain obligations assumes 'the possibility of proving what can only be apprehended directly by an act of moral thinking, ${ }^{25}$ Carritt asserts that 'we believe we have various kinds of obligations, for which we can discover no common ground, arising out of the various situations in which we think ourselves'. ${ }^{26}$

Rashdall's ideal utilitarianism appears to be caught between the more reformist and systematic classical utilitarianism of Sidgwick and the less or not overly systematic and more conservative pluralism of Ross. Sidgwick holds that the moral philosopher's job is to 'enunciate, in full breadth and clearness, those primary intuitions of Reason, by the

\footnotetext{
22 Indeed, Ross, Carritt, and Prichard claim that the promotion of good outcomes is a necessary condition on obligation. See Ross, RG 36, 162; Carritt, The Theory of Morals, 41-2, 54, 86, 139; and Prichard, MO 2-3, and RM 25. Thanks to Robert Shaver for this point and the references.

${ }^{23}$ Sidgwick, ME 200.

${ }^{24}$ Ross, $R G 41$, also 20 n. 1; and RG 17, also 34-9.

25 Prichard, MO 1; RM 36.

26 E. F. Carritt, Ethical and Political Thinking (Oxford: Oxford University Press, 1947), 69.
} 


\section{ANTHONY SKELTON}

scientific application of which the common moral thought of mankind may be at once systematised and corrected'. ${ }^{27}$ Indeed, the moral philosopher is intended to 'tell men what they ought to think, rather than what they do think'. ${ }^{28} \mathrm{He}$ is to provide system and unity even at the expense of conflict with common-sense morality. ${ }^{29}$ System is of such importance to Sidgwick that one of his main arguments against rivals to hedonism is that they fail to provide plausible accounts of how to 'systematise human activities'. Rashdall appears to approve of this modus operandi in the case of what makes right acts right. He maintains, for example, that:

if we are to attempt to defend these maxims of Justice and Benevolence as valid and selfconsistent judgements of the practical Reason, it is a matter of life and death to our position to find either a common denominator, in terms of which both principles could be expressed, or at least some third principle which should govern us in deciding between their respective claimsin deciding when to sacrifice quantity of good in favour of just distribution, and when to sacrifice justice of distribution in order that there may be more good to distribute. (TGE 1.266-7; also $E 57)$

His hostility to pluralist views of rightness is manifest. He thinks it is irrational to hold pluralist views denying that only consequences matter to the morality of actions (TGE 1.89-90,134; E 59), though he concedes that this is the view of common sense (TGE 1.83).

Ross maintains that his job is to describe what 'we' really think, morally speaking. ${ }^{31}$ Indeed, for him 'the main moral convictions of the plain man seem to me to be, not opinions which it is for philosophy to prove or disprove, but knowledge from the start'. These verdicts may contain some infelicities that it is the moral philosopher's job to eliminate on the basis of sober reflection. ${ }^{33}$ But when the ironed-out verdicts conflict with ethical principles like Rashdall's, then, Ross thinks, it is 'absurd' to 'repudiate' our 'actual apprehension' of what is morally required of us. ${ }^{34}$ It is, after all, more important to have a moral view that fits with the facts than a moral position that is theoretically elegant or simpler. ${ }^{35}$ This is the attitude that Rashdall holds in the case of his theory of value (PU 225; TGE 1.72-3). He claims that 'the only way of showing that pleasure is not the true end of life is by an appeal to one's own moral consciousness and that of others so far as it is revealed by word and deed' (TGE 1.70). But it is hard to combine this attitude with the one that Rashdall displays in his discussion of rival theories of rightness, where he seems hostile to what is a common-sense position. It seems odd to be so hostile to common sense in the case of what is right but not in the case of what is good, without some very compelling reason to be so. Rashdall himself provides no such reason. His position is therefore an unstable middle view between uniformly monistic classical utilitarianism on the one hand and uniformly pluralistic deontological intuitionism on

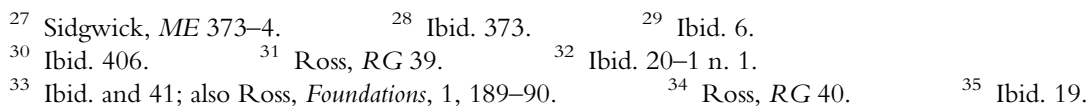


the other. The classical utilitarian does not encounter Rashdall's problem, since she argues that both the arguments against intuitionism and pluralism about the good must have the same structure. Both arguments must function to revise common-sense morality in line with monism. The Rossian, too, can insist that the arguments have the same structure. Both the theory of rightness and the theory of value must seek to capture the main elements of common-sense morality. It appears that Rashdall's arguments for and view about pleasure and valuable states of consciousness is at odds with the sort of argument he runs against intuitionism, for the arguments that are taken to impugn intuitionism are not taken to impugn his axiological pluralism.

Moore seems tempted by Rashdall's idea that all valuable states of affairs must contain some pleasure. In Principia he suggests that 'it might even be maintained that it is only wholes, in which some pleasure is included, that possess any great value'. ${ }^{36}$ In Ethics, he contends that it is not implausible to hold that 'no whole can ever have any intrinsic value unless it contains some pleasure'. ${ }^{37}$ Moore appears not to encounter Rashdall's problem, since Moore does not rely on the same sort of counter-argument in his dismissal of non-utilitarian competitors. ${ }^{38} \mathrm{He}$ does open himself up to another objection (if, in fact, he agrees that all valuable wholes must contain some pleasure). ${ }^{39}$ He argues that what has attracted many of its proponents to hedonism is the claim that all valuable wholes must contain some pleasure. They have erroneously inferred from this that only pleasure has intrinsic value, and that the value of a whole is always in proportion to the quantity of pleasure it contains. Their reasoning is as follows: 'let us call the pleasure which such a whole contains, $A$, and the whole remainder, whatever it may be, $\mathrm{B}$. We are then saying that the whole $\mathrm{A}+\mathrm{B}$ is intrinsically good, but that $\mathrm{B}$ is not intrinsically good at all. Surely it seems to follow that the intrinsic value of A $+B$ cannot possibly be greater than that of A by itself. ${ }^{, 0}$ Moore argues that this simply does not follow. It might be true that a whole containing only knowledge has no intrinsic value and that the intrinsic value of a whole containing both knowledge and pleasure has a value that is not strictly proportionate to the value of the pleasure alone. Moore rejects the claim that, "where a whole contains two factors, A and B, and one of these, $\mathrm{B}$, has no intrinsic goodness at all, the intrinsic value of the whole cannot be greater than that of the other factor, A'. ${ }^{41}$ Moore calls this the 'principle of organic unities' ${ }^{42}$ It claims that 'the amount by which the value of a whole exceeds that of one of its factors is not necessarily equal to that of the remaining factor ... the degree of intrinsic value of a whole is not always in proportion to the quantity of pleasure it contains'. ${ }^{43}$

36 Moore, PE 213, italics in original.

37 Moore, Ethics, 148, also 150, 153, italics in original.

38 Nor does he seem to defend his value theory by reference to common-sense axiological claims.

39 For Moore's diffidence, see Ethics, 150. It must be noted that to reject this view would render his position at least somewhat unacceptable.

40 Ibid. 148-9, italics in original.

41 Ibid. 150, italics in original.

42 Moore does not use this description in Ethics. See, instead, Moore, PE 27-36, 184.

43 Moore, Ethics, 151-2, italics in original. 


\section{ANTHONY SKELTON}

A similar objection might be launched against Moore's own view of rightness. It might be argued that what has attracted its proponents to the utilitarian view of rightness is the fact that all right actions must produce good outcomes. What the proponents of the utilitarian view of rightness have inferred from this claim is that only good outcomes matter to determining the morality of an action. However, while it might be the case that, say, an equitable economic distribution in the absence of good outcomes on balance is not morally obligatory, it does not follow that only good outcomes matter to the morality of an action. It might be the case that when an equitable economic distribution produces on balance good outcomes and we are choosing between this and another action producing the same amount of good on balance, but not involving an equitable economic distribution, that we ought to do that which produces the equitable distribution, because the morality of the action is affected (in this case) both by good outcomes and the fact that it involves an equitable economic distribution. Moore's own view of rightness is open (it seems) to an objection that he registers against hedonism. It does not follow from the fact that all right acts have good outcomes that only good outcomes matter to morality.

The fact that there are tensions in the arguments that Moore and Rashdall provide does not entail that the view of rightness that they defend is false. But the only thing that Rashdall and Moore have left when their arguments are turned aside is the claim that the view of rightness to which ideal utilitarians subscribe is self-evident. ${ }^{44}$ This claim remains deeply counter-intuitive to many, and Moore and Rashdall do seem to need to provide dissenters with reasons for accepting it. As Sidgwick puts it, 'when we are dealing with any subject where there is a conflict of opinion as to first principles, we can hardly refuse to give reasons for taking our side in the conflict: as rational beings conversing with other rationals it seems absurd that we should not be able to explain to each other why we accept [apart from noting its self-evidence] one first principle rather than another'. ${ }^{45}$

Moore and Rashdall might therefore try a different tack. They might argue that in the case of the right, deviations from the requirement to promote the good are paradoxical (E 53). ${ }^{46}$ Of intuitionism Rashdall and Moore might ask: Why is it right to refrain from $x$-ing (e.g. lying) when by $x$-ing (lying) one can prevent more $x$-ing (lying) from occurring (TGE 1.194)? It is paradoxical that we have a reason not to lie which is not in addition a reason to prevent more lying from occurring. In the case of the good no such paradox occurs when one, say, deviates from what has maximum net pleasure or opts for another value, for example, knowledge or virtue, at the expense of pleasure. It is not clear that there is anything paradoxical about sacrificing some pleasure for virtue. Admittedly, this is a controversial point, and it may not move Rashdall's and

\footnotetext{
${ }^{44}$ Rashdall may not have this, though he could simply revert to Moore's view.

${ }^{45}$ Henry Sidgwick, 'The Establishment of Ethical First Principles', Mind, 4 (1879), 106.

46 For this worry, see e.g. Robert Nozick, Anarchy, State and Utopia (New York: Basic Books, 1974), 30-2; and Thomas Nagel, The View from Nowhere (Oxford: Oxford University Press, 1986), 178 ff.
} 
Moore's deontological rivals. But at the very least it puts their opponents on the defensive, and this may suffice in this case.

\section{III}

Rashdall's theory of rightness is controversial and his arguments do not fare well under scrutiny. His legacy does not, therefore, lie in his defence of it. He also defends value pluralism. Pluralism about the good was popular in Rashdall's time, even amongst those who rejected his theory of rightness. ${ }^{47}$ It is therefore important to consider his arguments. It seems that his lasting contribution lies in his defence of this (popular) view.

Rashdall's main target is hedonism. He offers several arguments against the view. The one that he relies on most heavily explicitly engages Sidgwick. ${ }^{48}$ Rashdall argues that Sidgwick's theory contains at its core an internal or 'psychological contradiction' (E 64; also TGE 1.58), which forces him to abandon hedonism. The argument runs as follows: P1. Sidgwick says that 'as a rational being I am bound to aim at good generally, - - so far as it is attainable by my efforts, - not merely at a particular part of it'. ${ }^{49} \mathrm{P} 2$. Rational requirements generate a desire to do what is right and reasonable as such in rational agents. ${ }^{50} \mathrm{C} 1$. Therefore, the rational agent has a desire to aim at good generally. P3. Acting on the desire to aim at good generally may lead to self-sacrifice. P4. Self-sacrifice has no intrinsic value for the hedonist. ${ }^{51} \mathrm{P} 5$. This means that the rational agent will think (at least in numerous cases) both that he ought (or has conclusive reason) to be motivated to do the right thing and that this is a 'dead loss to himself' (E 64; also PU 217). ${ }^{52}$ P6. This state of mind is 'an impossible' one, or 'at all events one so rare that it might fairly be described as pathological' (E 64; also TGE 1.57). C2. Therefore, at the heart of Sidgwick's view there is a 'psychological contradiction' (E 64; also TGE 1.58). P7. In fact, the argument continues, 'the conviction that there is such a thing as duty, that one kind of conduct is intrinsically reasonable or right and another kind of conduct is intrinsically unreasonable or wrong, has almost invariably gone along with the conviction that right conduct, or the character or disposition which results in right conduct, is in and for itself a good and the greatest of goods' (E 64; TGE 1.59). If virtue is not an intrinsic good, then there is no subjective motive for acting in accord with the requirement to promote the good.

The whole force of the subjective hold which the precept 'be reasonable' has exercised over me, so long as I was unacquainted with the teachings of rational Utilitarianism, has lain in its

\footnotetext{
${ }^{47}$ See e.g. Ross, RG 134-41; Carritt, Ethical and Political Thinking, 83-95; and (it seems) Prichard, MO 5; RM 29.

${ }^{48}$ For versions of this argument, see PU 215-22; TGE 1.53-9; and E 63-5. I construe it as being primarily about motivation.

49 Sidgwick, ME 382

${ }^{50}$ Ibid. 34. $\quad{ }^{51}$ Ibid. 400-1. $\quad{ }^{52}$ Ibid. 502.
} 


\section{ANTHONY SKELTON}

inseparable connexion with another conviction - that it was intrinsically noble for me to act in this way, and that to act in accordance with the reasonable was a good to me, a greater good than I could obtain by pursuing the pleasure which you tell me is the only true good. (TGE 1.57-8; also 59)

P8. Reason does provide a subjective motive for acting in accordance with the requirement to promote the good (TGE 1.57, 59): a theory which fails to provide a 'logical basis for that rational justification of the individual life of Duty ... must be relegated to the domain of poetry' (PU 226). C3. Therefore, virtue is a good and (for Rashdall) the highest good.

Rashdall took this to be a devastating blow to Sidgwick's hedonism, but his argument seems to apply equally to views other than hedonism, for example, the view according to which only knowledge, achievement and pleasure, but not virtue or a rightly oriented will, are intrinsically good. In this case, as in the case of hedonism, virtue is at best an instrumental good. Rashdall will no doubt argue that this view kills the impulse to promote the good by denying virtue intrinsic value. The 'inner logic' of these views compels their proponents to endorse the view that virtue or the rightly directed will is intrinsically good.

One initial worry about the argument is that Rashdall writes as if there is no motivation to do what is right unless there is a benefit to the agent. ${ }^{53}$ This suggests that one is motivated only by one's own good. This seems to be in tension with Rashdall's rejection of psychological egoism, which he concludes is 'hopelessly at variance with psychological facts' (E 20). More specifically, he rejects the view on the grounds that there are disinterested desires, one example of which is the desire to promote things other than one's own (greatest) good (TGE 1.27-9, 38-43; E 16-21). In reply, Rashdall can note that he does explicitly say that there is a desire to do what is right and reasonable, but that it only 'sometimes induces... [agents] actually to do the reasonable thing even at the cost of their own good (i.e. pleasure) rather than the unreasonable', and that its powers have been 'enormously exaggerated' (E 63-4; CE 114). Rashdall seems to think that we are sometimes (albeit rarely) motivated to do the right thing by its reasonableness at a cost to ourselves, but often we are not: in these latter, more numerous cases the thought that virtue is intrinsically good supplies the remaining motivation.

But two further objections arise. First, Sidgwick might reply that if agents demand compensation or some kind of benefit in order to obey moral requirements, then they are best understood as agents who are unconcerned with morality. If this is so, then they seem to be the kind of creature who is unmoved by moral or rational considerations, and it is not clear that (a) positing that virtue has value or that value lies in a correctly oriented will is able to supply what Rashdall requires, or that $(b)$ we should be terribly worried about these sorts of individuals (at least in moral philosophy). If one

\footnotetext{
${ }^{53}$ I owe this objection to Thomas Hurka.
} 
needs extra motives beyond what reason or rightness itself provides to act morally, then one seems uncommitted to morality, just as one who requires incentives to be just might be assumed to be uncommitted to the most plausible principles of justice.

Second, Rashdall's argument turns on an empirical claim. He suggests this when he writes that the acceptance of rationalistic Hedonism kills and eradicates all those impulses upon which it has to depend for the practical fulfilment of its own precepts', that 'the desire to escape ... one-sidedness is not by itself a very powerful motive of conduct when it is pronounced to have no intrinsic value' (TGE 1.58), and that the motive to do the right thing is weak (TGE 1.57; CE 114). However, if acceptance is the problem, then perhaps the right reply for the hedonist is to simply discourage acceptance rather than to reject his view. It is certainly open to the hedonist to encourage the adoption of ends other than hedonism if she thinks this will promote more pleasure over the long run. Furthermore, if the desire to escape one-sidedness really is less than potent, then the hedonist could advocate for the education of desire so that agents will be motivated more thoroughly by the natural desire 'that there should be harmony between... [their] feelings and aims and those of... [their] fellow creatures', ${ }^{54}$ or come to see that pleasure and the absence of pain is an end which 'satisfies our imagination by its vastness, and sustains our resolution by its comparative security'. 55

Moore does not rely on this sort of argument against Sidgwick's hedonism. Instead, his arguments rely on reflective intuition and on the use of the isolation method. ${ }^{56}$ Like Moore, Rashdall believes that there are self-evident intuitions which pertain to his claims about what has intrinsic value, though he shows no sign of employing the isolation method. In describing his view, he writes that, 'besides this preference of the truly good in conduct or character there were many other elements in the ideal state of a human soul besides the Altruism of its volitions and the pleasantness of its sensations; and when we faced the question, how we know these things to be good in various degrees, we were obliged to answer "We know it intuitively or immediately...", (TGE 1.100; also E 22, 40; CE 43; TGE 1.93). ${ }^{57}$ On the basis of these intuitions Rashdall suggests that we can explain and justify the thoughts that some pleasures are bad, for example, pleasures taken in cruelty and lust (E 70; TGE 1.73, 98-100), and that some pleasures are more important than others irrespective of intensity and duration (TGE 1.72, 73; E 67-9; TGE 2.33, 38; CE 44). ${ }^{58}$ In so doing, he thinks

\footnotetext{
54 John Stuart Mill, Utilitarianism, ed. Roger Crisp (Oxford: Oxford University Press, 1998), 79.

55 Sidgwick, ME 404.

${ }^{56}$ See e.g. Moore, PE 83-5, 92-4, 187 ff.; Moore, Ethics, 146-7.

57 Rashdall notes that in saying that something is immediately known he means that our knowledge of it is 'not obtained by inference or deduction from something else in the way in which the Utilitarian supposes his judgements to be deductions from rules got by generalization from experience' (TGE 1.93 n. 1).

58 These views were widely held amongst Rashdall's contemporaries; see e.g. Ross, RG 136-8, and Carritt, Ethical and Political Thinking, 92-3. For recent hedonist replies, see Fred Feldman, Pleasure and the Good Life (Oxford: Oxford University Press, 2004), and Robert Shaver, 'The Appeal of Utilitarianism', Utilitas, 16 (2004).
} 


\section{ANTHONY SKELTON}

'the more glaring discrepancies between logical Utilitarianism and the moral ideal recognized by most good men will disappear' (E 65; also TGE 1.72$)$. Rashdall takes the argument for his self-evident intuitions even further than this. He holds that ideal utilitarianism has practical implications that are more acceptable to common-sense thinking than those of classical utilitarianism, and that this affords a further mechanism for the defence and the epistemic justification of it (PU 219; TGE 1.189-215; E 65-7). Moore agrees with Rashdall that, for example, cruelty and lust are 'great positive evils' because they involve loving what is evil. ${ }^{59}$ But he does not seem to argue that intuitions - for example, that virtue is intrinsically good - are further justified by the fact that they are able to explain and justify elements of 'ordinary moral consciousness' (TGE 1.73; also 72, 97). Nor does Moore attempt to defend the view by showing how it has more palatable practical implications than its rivals.

These differences between Moore and Rashdall point to unique and novel aspects of the latter's defence of ideal utilitarianism. Moore fails to exploit these avenues for two reasons. First, he accepts a specific view about self-evidence, according to which a self-evident proposition is one for which no reason can be given. ${ }^{60}$ Rashdall seems sometimes to agree with Moore about self-evidence (see e.g. TGE 1.100). However, his general argumentative strategy suggests otherwise. Indeed, he seems to rely on an epistemology that involves appealing to self-evidence and coherence with commonsense morality for justification. ${ }^{61}$ Second, Moore denies that differences in value theory entail differences in practical directives. ${ }^{62}$ In a rather snotty review of The Theory of Good and Evil, Moore took Rashdall to task for not adequately demonstrating practical divergence between ideal and hedonistic utilitarianism, arguing that 'obviously every action which does in fact produce a maximum balance of pleasure might always also produce such other results as would give the total a maximum of intrinsic value; and considering how immensely complicated the total results of actual actions are, it is very difficult to be sure that this is not the case' ${ }^{63}$ Yet, it is not implausible to think that a divergence between the two views will occur in practice. ${ }^{64}$

At any rate, Rashdall advocates for divergence, and he exploits the putative divergence to his advantage. He argues that ideal utilitarianism is more plausible than

59 Moore, PE 208; for his arguments, see 208-11.

60 Ibid., pp. x, 143, 148-9. Ross seems to have the same view; see RG 20 n. 1, 30.

61 For this interpretation of Sidgwick's epistemology, whom Rashdall may be following, see Robert Shaver, Rational Egoism (Cambridge: Cambridge University Press, 1999), 62-71. For worries about Shaver's interpretation, see Anthony Skelton, 'Schultz's Sidgwick', Utilitas, 19 (2007), and 'Henry Sidgwick's Moral Epistemology', Journal of the History of Philosophy, 48 (2010).

62 Moore, PE 158. This seems to be T. H. Green's view; see Green, Prolegomena to Ethics, ed. A. C. Bradley (Oxford: Clarendon Press, 1883), sec. 332. Sidgwick sides with Rashdall; see Sidgwick, ME 8-9.

63 G. E. Moore, 'Review of The Theory of Good and Evil: A Treatise on Moral Philosophy', Hibbert Journal, 6 (1907-8), 449, italics in original. Although Moore's tone in this review is less than effusive, he later warmed to the book. In Ethics, he says that if the reader wishes 'to become acquainted with the principal works on Ethics which have been written by writers still living, I think I can hardly do better than recommend him to read, first of all, Dr. Hastings Rashdall's Theory of Good and Evil' (p. 157).

64 For this point, see Thomas Hurka, 'Moore in the Middle', Ethics, 113 (2003), 616 n. 72. 
hedonistic utilitarianism because the former is able to capture common-sense 'duties or virtues' which are 'incapable of being reconciled' with the latter (TGE 1.188, 189). He has in mind especially the particular virtues of purity, temperance, veracity, and humility, among others.

In the case of purity and temperance his arguments are not convincing. For Rashdall, the virtue of purity is the promotion of 'a state of feeling which the clearest moral insight and the highest spiritual experience of the race have decided to be incompatible with sexual indulgence outside a relatively permanent monogamous union' (TGE 1.197). It is in dealing with this virtue, Rashdall writes, 'that hedonistic-utilitarian explanations of Morality break down most hopelessly' (TGE 1.197). This is too hasty. In his discussion of purity, Sidgwick, for example, says that we must place a high value on purity if we are to maintain that 'higher type of sexual relations' and to contribute to 'the maintenance... of the permanent unions which are held to be necessary for the proper rearing and training of children'. ${ }^{65}$ The requirement of purity forbids 'all extranuptial intercourse of the sexes'. ${ }^{66}$ Indeed, 'the Virtue of Purity may be regarded as providing a necessary shelter under which that intense and elevated affection between the sexes, which is most conducive both to the happiness of the individual and to the wellbeing of the family, may grow and flourish'. ${ }^{67}$ Because the impulse that purity regulates is 'so powerful and so sensitive to stimulants of all kinds... the aversion to impurity must extend far beyond the acts that primarily need to be prohibited, and include in its scope everything (in dress, language, social customs, etc.) which may tend to excite lascivious ideas'. ${ }^{68}$ This seems to suggest that on the question of purity, hedonistic and ideal utilitarian views are quite close in their implications. ${ }^{69}$ They are at least close enough that the case is not as easy as Rashdall makes it out to be.

There may be some differences between Sidgwick and Rashdall on purity. Rashdall insists that the only permissible sexual relations occur within the confines of monogamous and relatively permanent marriage (TGE 1.197, 198). Sidgwick avoids stating that monogamous marriage is the only place in which it is permissible to have sex, and the fact that he says that there is nothing intrinsically wrong with sex outside of marriage makes the view more rather than less plausible. ${ }^{70}$ If Sidgwick's view turns out to lead to a more relaxed account of purity and therefore more 'impurity' than he lets on, then this seems to imply that it has an advantage over ideal utilitarianism. Our current views of sexual relations seem to be more rather than less in line with hedonistic utilitarianism.

In the case of temperance, Rashdall claims that ideal utilitarianism forbids drunkenness (TGE 1.99, 202-3; E 70). This is a benefit to ideal utilitarianism because 'the

65 Sidgwick, $M E$ 452, 450. 66 Ibid. 450 .

67 Ibid. $452 . \quad 68$ Ibid. 453.

69 What Sidgwick says also suggests that, pace Rashdall, the two have similar implications for divorce (TGE 1.200).

70 Sidgwick, $M E 358$. 
healthy moral consciousness does condemn as intrinsically degrading even the most occasional act of deliberate drunkenness' (TGE 1.203; also 99). Rashdall may be right that on the issue of drunkenness hedonistic utilitarianism is more liberal than ideal utilitarianism. But it is far from clear that this is a mark against it. Surely, an occasional act of deliberate drunkenness which will not knowingly lead to alcoholism or other obvious malfeasance is not wrong in itself. ${ }^{71}$ In reply, Rashdall might remind us of his account of drunkenness: 'the voluntary extinction of consciousness and self-control for no purpose but momentary pleasure or satisfaction of impulse' (TGE 1.203 n. 2). The danger with this reply is the narrowness of the definition, for the narrower the definition of drunkenness the more likely it is that we will see no difference between hedonistic and ideal utilitarianism in terms of their practical judgements about it. If the loss of consciousness and self-control is great the hedonist can plausibly argue that this sort of drunkenness is forbidden because of its long-term negative effects, which would seem to be considerable. If the loss is not great because the drunkenness is merely occasional, it is unclear what the problem appears to be. Again, the hedonistic utilitarian seems to be closer to our current views than the ideal utilitarian.

Rashdall's appeal to common-sense opinions (prevalent at his time) on matters of purity and temperance does not attract us to his view. Fortunately, he may be able to distance himself from them. He notes that we are not infallible judges on moral matters (TGE 1.145). To combat error, we need a mechanism for 'distinguishing mere feelings or aversions which may be only prejudices due to inheritance or environment or superstition from real judgements of value' (TGE 1.211-12; also 85; E 54-5). He suggests a 'test', which begins by asking ourselves the following question: 'does the spontaneous aversion or apparent intuition disappear after full reflection upon the act itself as well as upon all circumstances and consequences?' (TGE 1.212). ${ }^{72}$ If one's answer is affirmative, then the judgement is put aside; if one's answer is negative, then the judgement stands. Rashdall might argue that on sober reflection the judgements regarding purity and temperance turn out not to be authentic judgements of value, but, rather, 'only prejudices due to inheritance or environment or superstition' (TGE 1.211). ${ }^{73}$ In the case of purity, Rashdall can simply drop the emotion or feeling which he says the virtue of purity promotes. He can avoid the worries about his view by divesting himself of an intrinsic value (or at least aspects of it) that he sometimes lists together with the intrinsic values of virtue, intellectual activity, and mere pleasant feeling, namely, 'various kinds of affection or social emotion' (E 70; also TGE 2.37). The value that purity apparently promotes is obviously a kind of affection or emotion. Since this turns out not to reflect a real judgement of value, it would be put aside as per

${ }^{71}$ Ibid. 329: 'it would be going too far to state, as a maxim supported by Common Sense in respect of sensual pleasures generally, that they are never to be sought except when [sic] they positively promote those of a higher kind.' Rashdall thinks that drunkenness is justified only if it promotes some greater good (E 58-9).

${ }^{72}$ In this context, Rashdall defines 'intuition' as 'an apparently unaccountable repugnance to some kind of conduct' (TGE 1.212).

${ }^{73}$ It is interesting to compare his objection to drunkenness with his lax attitude on smoking (TGE 1.93). 
Rashdall's test. In the case of temperance things may be a little less clear, because the judgement about drunkenness may follow from his views about intellectual values. But perhaps this is not a problem if he means to rule out only the type of drunkenness outlined above (though, as noted, in this case he no longer has a clear advantage over classical utilitarianism).

Rashdall can move from this defensive stance to a more offensive stance. He can argue that armed with his three goods he can demonstrate that ideal utilitarianism is superior to hedonistic utilitarianism given its coherence with (reflectively endorsed) common-sense moral beliefs. This is particularly true of its practical directives regarding the virtues of veracity and of humility.

As regards veracity, Rashdall maintains that, "upon hedonistic assumptions the exceptions would be much more numerous than would commend themselves at least to a well-brought-up Englishman' (TGE 1.192). Veracity consists in loving the truth and speaking the truth, and the value that it promotes is the correct use of our rational faculties, those that enable us 'to pursue, to communicate, and to love the truth' (TGE 1.193; also 188, 194). Rashdall notes that veracity admits of exceptions, including 'the actual deception practised by detectives, or by private persons towards a brigand inquiring the whereabouts of his victim, or to the denial of bad news to sick persons, or to lies told for the preservation of important secrets, or to the employment of ancient formulae ... which nobody takes quite literally' (TGE 1.193; also 92-3). On the face of it, there is no difference here with, for example, the hedonistic utilitarianism of Sidgwick, who lists the same sort of exceptions (ME 315-16, 345, 448-9).

However, while it might be true that they accept some of the same kinds of exceptions, further reflection would seem to suggest, pace Sidgwick, that hedonism permits a greater number of exceptions to veracity than ideal utilitarianism. Rashdall might, for instance, argue that his view does a much better job of explaining veracity in public life. What makes it wrong for politicians and their cognates to lie to their citizens is that in lying they delude and deceive their citizens, leaving them as a consequence less likely to use their rational faculties properly and to make sound decisions. In addition, it makes them (upon learning of the mendacity) less likely to appreciate and seek out the truth, especially regarding political matters. This sort of behaviour tends to cause people to be jaded and disengaged. In response, they tend to gravitate toward less important matters (e.g. gossip and televised sporting events). It seems implausible to think that this state of affairs would be desirable if it contained on balance more pleasure than the option that Rashdall might advocate. Indeed, we think that a politician's job is not to provide us with comfortable delusions but (if necessary) bitter truth: it would be counterintuitive for a politician to consider what the balance of pleasure would be if she or he lied before making public policy announcements in the vast majority of cases. The commonsense view is that it is best to tell the truth unless untruth is required to prevent (for example) serious loss of life or protect state secrets from being made known to those who might do harm. A small increase in pleasure would not suffice. Rashdall's view seems to supply a highly plausible explanation of just these intuitions. 
Given this, it is ironic that in their dispute about clerical veracity Rashdall accuses Sidgwick of being a 'Kantian rigorist'. ${ }^{74}$ Both Rashdall and Sidgwick agree that Anglican ministers do not have to conform to the literal interpretation of what they express in making pledges and reciting creeds. However, Sidgwick thinks that if an Anglican minister says 'I believe in the virgin birth', but he does not believe it, then he is lying, and must therefore break his ties with the established church. His view is that 'no gain in enlightenment and intelligence which the Anglican ministry may receive from the presence of such [bright and thoughtful] men can compensate for the damage done to moral habits and the offence given to moral sentiments by their example' ${ }^{75}$ Rashdall thinks that the statement about the virgin birth can be interpreted to mean something quite different from what it appears to mean, and much of his discussion in reply to Sidgwick is spent trying to establish this and other similar facts. ${ }^{76}$ His more serious disagreement is normative. Rashdall holds, contra Sidgwick, that the cost to virtue and moral habits - 'a very small evil'-is outweighed by the gain in intelligence and enlightenment that progressive ministers bring and that will help to preserve the church, in its social and moral role. ${ }^{77}$ What is important here is that, whether or not he is right, Rashdall can argue that his version of ideal utilitarianism is better able to explain the dispute between the two. If Sidgwick is right, Rashdall can argue that he is able to explain why Sidgwick's position is the right one better than Sidgwick's own hedonistic utilitarianism, for his ideal utilitarianism grants that virtue is the most important good and outweighs intellectual and other goods in some (and perhaps even in these sorts of) situations. Rashdall might strengthen his case by noting that on Sidgwick's own view the appeal to what might provide people with net pleasure plays no or very little role in determining what Anglican ministers should do. ${ }^{78}$ If Rashdall is right about the normative matter, on the other hand, that the intellectual benefits are weightier, then again he can claim that his ideal utilitarianism provides the best explanation, since it grants that in certain cases intellectual goods outweigh the goods of virtue.

Rashdall suggests that humility is the due regulation of 'pride or the high estimation of self', resulting in an under-appreciation of one's abilities (TGE 1.204). He thinks

${ }^{74}$ Hastings Rashdall, 'Professor Sidgwick on the Ethics of Religious Conformity: A Reply', International Journal of Ethics, 7 (1897), 138. This paper is a reply to Henry Sidgwick, 'The Ethics of Religious Conformity', International Journal of Ethics, 6 (1896). For a response to Rashdall, see Henry Sidgwick, 'Clerical Veracity', in Practical Ethics: A Collection of Addresses and Essays, ed. Sissela Bok (Oxford: Oxford University Press, 1998).

${ }^{75}$ Sidgwick, 'The Ethics of Religious Conformity', 289.

${ }^{76}$ Sidgwick is surely right that there is no way to interpret this statement so that a person uttering it under these circumstances is not lying.

77 Rashdall, 'Professor Sidgwick on the Ethics of Religious Conformity: A Reply', 166.

${ }^{78}$ Sidgwick might suggest that he is not here arguing as a hedonistic utilitarian: instead, he is employing the method that he sketches in Practical Ethics for the purpose of doing practical ethics, which involves reliance on the main rules of common-sense morality or 'middle axioms', not his brand of utilitarianism. This may not help him, since Rashdall can still argue that his view is closer to common-sense morality than Sidgwick's. For discussion of Sidgwick's practical ethics, see Sissela Bok, 'Henry Sidgwick's Practical Ethics', Utilitas, 12 (2000), and Anthony Skelton, 'Henry Sidgwick's Practical Ethics: A Defence', Utilitas, 18 (2006). 
that this presents the ideal utilitarian with a kind of puzzle. On the one hand, it insists on a truthful assessment of one's 'own powers and merits' (TGE 1.205); on the other, it is cognizant of the troubles associated with pride or thinking too much of oneself. $\mathrm{He}$ solves this conflict by arguing that we ought to aim at a truthful assessment of ourselves because this is 'most favourable to moral progress, to intellectual self-development, and to social usefulness' (ibid.), and that we ought not to spend too much time dwelling 'with satisfaction' on our own merits, for two reasons. First, because any plausible ideal places too large a chasm between 'ideal and the actual performance... even of a good man to permit him any great self-complacency at the thought that he is better than the majority of his neighbours' (ibid.), and second, because 'the good man cares too much for others to derive pleasure from the thought that they are worse than himself' (TGE 1.206).

Two things seem right about Rashdall's discussion. First, he does a nice job of articulating why humility presents us with a problem. On the one hand, we think that it is important to have a truthful assessment of our abilities and merits (if any) but, on the other, we want to ensure that this does not interfere with further growth (virtuous or otherwise) or other social relations. He provides a more compelling discussion of humility than one which conducts the discussion wholly in terms of 'social inconveniences' of overestimating one's abilities or pleasures associated with contemplating them. Second, he seems to be able to capture why it is inappropriate to have estimates that are too high and estimates that are too low. He can rightly explain that humility rests in part on the fact that the virtuous person does not take pleasure in the fact that he is better than other people, that there is something inappropriate about noting one's superior abilities and in taking pleasure in this fact. Indeed, he notes further that the correct response (though not entirely without difficulty) consists in feeling sorrow that others are unable to attain the same sort of status or possess the same merits. He can also explain why it is a good thing to have a truthful assessment of one's abilities and merits even if this leads to discomfort and displeasure. He can explain why a woman who thinks erroneously that she is best suited only to be a housewife ought to be brought to a better assessment of her abilities even if this requires or entails a sacrifice in her degree of contentment with her life.

There is one wrinkle in Rashdall's argument against hedonistic utilitarianism. As noted above, he is not afraid to thwart common-sense judgement in the case of his views about right and wrong. He concedes that, in the case of the virtue of purity, 'the developed moral consciousness does seem most nearly to assume the form which Intuitionism gives to all ethical precepts - that of a prohibition to do certain acts, a prohibition which gives no further account of itself, and which positively forbids any calculation of consequences or admission of exceptions' (TGE 1.197). He is happy to revise the judgement: 'While strongly insisting that the moral consciousness in its highest development does condemn all sexual indulgence outside monogamous marriage, I should contend that this prohibition admits of being stated in the form of a judgement as to the ultimate value of an end' (ibid.). This is an example of a more 


\section{ANTHONY SKELTON}

general strategy that Rashdall uses against the intuitionist (see e.g. TGE 1.92-3). He notes that the latter declares that certain things are right or wrong and that this is the end of the matter: we typically 'pronounce judgements upon individual acts without conscious reflection on the consequences to any one, still less on the ultimate consequences to social well-being' (E 51). He does not accept that this furnishes us with reason to believe that these intuitions are a correct account of what it is right to do, or for thinking that moral reasons (in this case) are deontological in nature. He writes that 'the question is not so much as to the existence of intuitions or apparent intuitions about conduct, but as to the source of their ultimate authority or validity, and consequently as to their finality' ( $E 52$; italics in original). He goes on to impugn their finality and validity.

He does not permit this move to the hedonist. We have seen that Rashdall is clearly opposed to occasional drunkenness. He notes that the hedonist might explain the wrongness by appeal to 'remoter social ill consequences' (TGE 1.203). He rejects this explanation, for 'we see the act to be intrinsically disgusting, and there is an end of the matter' (ibid.). This seems inconsistent. Why allow impugning explanations in the case of common-sense deontological claims, but not in the case of common-sense axiological claims? The same worry emerges in Rashdall's treatment of hedonistic attempts to explain the morality of veracity and the dubiety of bullfighting (TGE 1.192, 99). In the case of veracity he maintains that 'it is not necessary to deny that the encouragement even of such intellectual pursuits as are of the least direct and obvious social utility does lead to an increase of pleasure on the whole, but our feeling about them is not based upon any such doubtful calculations' (TGE 1.192). In his discussion of bullfighting, Rashdall writes that if the pleasure generated by a bullfight outweighs the pain, 'a humane man would condemn the spectacle all the same. He will pronounce such pleasures of inhumanity bad, quite apart from the somewhat dubious calculation that the encouragement of inhumanity in one direction tends to callousness in another' (TGE 1.99, also 73; E 66-7). But it surely is open to an intuitionist to say that certain things seem wrong, for example, lying, injustice, and so on, because they are wrong, not on account of some calculation, 'dubious' or otherwise, derived from ideal utilitarianism.

Rashdall need not worry too much, it seems, about this argument, provided that he can show that hedonism conflicts with reflective common-sense judgements. In this case, he will not have to argue- as Prichard, Ross, and Carritt often do in their attack on ideal utilitarianism-that even if it is not at odds with common-sense morality, classical utilitarianism provides the wrong explanation of common-sense moral claims. Since he might be accused of the same, he must be careful that his worries about hedonistic utilitarianism are that it cannot capture certain reflective common-sense moral beliefs rather than that it provides the wrong explanation of these beliefs. In the case of veracity and humility, he seems to do just this. 


\section{IV}

Rashdall's appeal to self-evidence and coherence with common-sense morality in his argument for ideal utilitarianism distinguishes him from Moore. This is not all. This argumentative strategy connects and makes him highly relevant to subsequent defences of the view, where the attempt is to support it by noting how it is at least as close to common-sense morality as its rivals. This is the strategy of, for example, the ideal utilitarians W. A. Pickard-Cambridge, A. C. Ewing, and Oliver Johnson. ${ }^{79}$ Rashdall therefore seems to make a more lasting and perhaps more significant contribution to the defence of ideal utilitarianism than does Moore. But his defence is not entirely continuous with more recent attempts to vindicate his position, for unlike PickardCambridge, Ewing, and Johnson, he does not (in earnest) attempt to defend ideal utilitarianism against deontological rivals using this mechanism. ${ }^{80}$ His main attempt is to show that ideal utilitarianism is more plausible than its hedonistic foe. This is probably because Rashdall felt that deontological frameworks were not formidable rivals. He did not anticipate Prichard and Ross. He is discontinuous in another way. The subsequent defences of ideal utilitarianism attempt to argue that the view can capture deontological intuitions or rival views by expanding the range of goods beyond those of virtue, knowledge, and mere pleasant feeling, among other states of consciousness. ${ }^{81}$ These views attempt to capture such intuitions by arguing that, for example, justice is a good and that breaking a promise is an evil. Rashdall cannot do this because he thinks that only states of consciousness have intrinsic value, and because promise-breaking and justice are not states of consciousness they cannot be valuable. Nevertheless, Rashdall did open up a new avenue for the defence of ideal utilitarianism, which makes study of his works important to understanding the development and the philosophical viability of this position.

\footnotetext{
79 See e.g. W. A. Pickard-Cambridge, 'Two Problems About Duty (I.)', Mind, 41 (1932); 'Two Problems About Duty (II.)', Mind, 41 (1932); 'Two Problems About Duty (III.)', Mind, 41 (1932); Ewing, 'Recent Developments'; Oliver A. Johnson, Rightness and Goodness (The Hague: Martinus Nijhoff, 1959) and 'Rightness, Moral Obligation, and Goodness', Journal of Philosophy, 50 (1953).

${ }^{80}$ Sometimes Rashdall suggests this defence (TGE 1.72-3, 97).

81 This is the strategy of Ewing and Johnson; see also Susan Brennan, 'Ross, Promises, and the Intrinsic Value of Acts', Lyceum, 1 (1989), and Robert Shaver's chapter in this volume (Chap. 7).
} 